\title{
Isolated pancreatic tail laceration after blunt abdominal trauma: A rare entity
}

\author{
Batına künt travma sonrası izole pankreas kuyruk laserasyonu: Nadir bir tablo
}

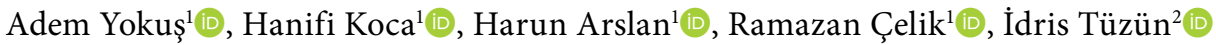 \\ ${ }^{1}$ Department of Radiology, Van Yüzüncü Yll University Faculty of Medicine, Van, Turkey \\ ${ }^{2}$ Department of Emergency Medicine, Van Yüzüncü Yıl University Faculty of Medicine, Van, Turkey
}

\begin{abstract}
Pancreatic injuries originating from blunt trauma are considerably rare. Diagnosis and treatment are difficult because of retroperitoneal localization of the organ. In the early term, normal physical examination and normal pancreatic amylase levels may cause the diagnosis to be overlooked. Contrastenhanced computed tomography is the major diagnostic tool of intra-abdominal injuries. In this article, we report a case of a child who fell from his bicycle resulting in admission and was diagnosis of isolated pancreatic tail injury accommodated by computed tomography findings.

Keywords: Computed tomography, pancreatic tail, trauma.
\end{abstract}

öz

Künt travmadan kaynaklanan pankreatik yaralanmalar oldukça nadirdir. Tanı ve tedavi, organın retroperitoneal yerleşimi nedeniyle zorlayıcıdır. Erken dönemde normal fizik muayene ve normal pankreas amilaz düzeyleri tanının atlanmasına neden olabilir. Kontrastlı bilgisayarlı tomografi karın içi organ yaralanmalarında majör görüntüleme yöntemidir. Bu yazıda bisikletten düşme sonucu başvuran ve izole pankreas kuyruk yaralanması tanısı konulan bir çocuk olgu bilgisayarlı tomografi bulguları eşliğinde sunuldu.

Anahtar sözcükler: Bilgisayarlı tomografi; pankreas kuyruğu, travma.

Blunt traumas constitute more than $80 \%$ of abdominal traumas in childhood. In blunt traumas, the pancreas is rarely injured due to anatomic localization compared to other solid organs. Blunt traumatic injury of the pancreas accounts for less than $2 \%$ of all abdominal injuries. ${ }^{[1,2]}$ Because the pancreatic injury is rare, it is usually missed or diagnosed may be delayed. ${ }^{[3]}$ Blunt pancreatic injuries occur frequently in childhood after cycling accidents. ${ }^{[4]}$ Here, we present a case of blunt abdominal trauma in a boy with pancreatic tail injury. The aim of this case report is to emphasize current diagnostic methods and treatment options for this rare condition.

\section{CASE REPORT}

A nine-year-old boy was admitted to the emergency department after fall from bicycle with a complaint of pain in the left upper quadrant. He was vitally stable. Physical examination revealed mild redness in the abdomen and tenderness in the entire abdomen, especially in the epigastric region. Perisplenic free fluid was detected in the abdominal ultrasonography (US). Laboratory investigations on admission revealed his white blood cell count of $19.800 / \mu \mathrm{L}(4.000-10.300)$, hemoglobin was $12.6 \mathrm{~g} / \mathrm{dL}(13.5-17.5)$, serum amylase was $937 \mathrm{IU} / \mathrm{L}$ (25-125) and serum

Received: April 04, 2019 Accepted: April 26, 2019 Published online: July 31, 2019

Correspondence: Adem Yokuş, MD. Van Yüzüncü Yıl Üniversitesi Tıp Fakültesi, Radyoloji Anabilim Dalı, 65080 Tuşba, Van, Turkey. Tel: +90 432 - 2150470 e-mail: drademyokus@gmail.com 

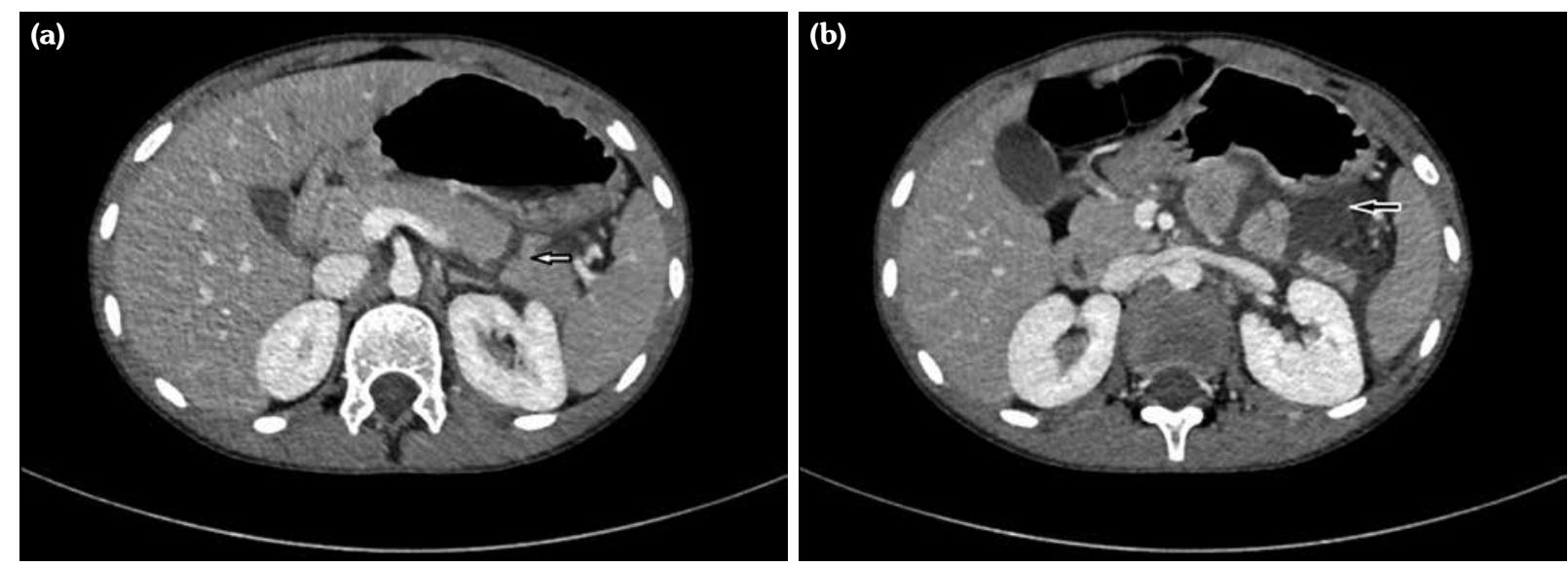

Figure 1. (a) Contrast-enhanced axial computed tomography scans; there is a transection through the tail of the pancreas and (b) free fluid in the perihepatic and perisplenic spaces.

lipase was 966 IU/L (8-78). Contrast-enhanced computed tomography (CT) scan of the abdomen was revealed a transection through the tail of the pancreas (Figure 1a) and free fluid in the perihepatic and perisplenic spaces (Figure 1b) without any other organ injury. Because the patient was hemodynamically stable and there was no evidence of pancreatic duct injury, he was treated conservatively (bowel rest, fluid resuscitation, nasogastric tube and analgesia). The patient was discharged with cure eight days after admission.

\section{DISCUSSION}

Trauma to the pancreas is not common, and isolated pancreatic trauma is even less common. The pancreas lies anterior to the vertebral column and may be compressed against it. ${ }^{[5,6]}$ Blunt pancreatic injury occurs when a blow to the epigastric area results in compression of the pancreas between the vertebral column and the anterior abdominal wall. This usually occurs on compression against the steering wheel in a motor vehicle accident in adults, from bicycle handlebar injuries in children, and from child abuse in infants. Two third of blunt pancreatic injuries are seen in the body of pancreas and the rest is seen equally in the head, neck and tail. Our case was a rare pancreas tail injury and was not accompanied by other organ injuries.

Pancreatic injury is more common in children and young adults because they have a thinner protective fat layer that surrounds the pancreas.
Injury to the pancreas is frequently accompanies with injuries to other organs, particularly the duodenum, and this may cause early death of the patient. ${ }^{[7]}$ An isolated pancreatic injury may be missed or the diagnosis may be delayed because the initial symptoms and signs of pancreatic injury are subtle, and this may contribute to the morbidity and mortality associated with this injury.

The diagnosis of blunt pancreatic injury should be suspected in patients with epigastric or diffuse abdominal tenderness, leukocytosis, or epigastric abdominal wall ecchymosis. In patients with a history of a steering wheel compression of the epigastrium during a motor vehicle or handlebar accident, the clinical suspicion of pancreatic injury should be aroused and careful additional investigative studies pursued regardless of the degree of abdominal pain. Studies have demonstrated that the elevation of amylase in both serum and peritoneal lavage fluid is neither sensitive nor specific for the diagnosis of pancreatic injury. Contrastenhanced CT is the diagnostic modality of choice for evaluating stable patients after blunt abdominal trauma. Helical multislice CT, which has both sensitivity and specificity as high as $80 \%$, represents the best noninvasive diagnostic method for the detection of pancreatic injury. ${ }^{[8]}$ However, particularly in the initial phase, CT may miss or underestimate the severity of the damage; normal initial findings do not exclude pancreatic injury, and repeated $\mathrm{CT}$ in the light of continuing symptoms may improve its diagnostic efficacy. ${ }^{[9]}$ 
The management of blunt pancreatic injuries has relied heavily on determining the severity of the injury, the location of the injury, and the presence or absence of associated intra-abdominal injuries. Surgical approach is required in adjacent vascular and pancreatic duct injuries. However, nonoperative conservative treatment is common in pancreatic trauma. Therefore, it is necessary to determine whether or not there are signs of Wirsung duct injury and duodenal injury. Morbidity and mortality rates of isolated pancreatic trauma are directly related to the presence of damage to the pancreatic duct. In the absence of injury to the duct, close monitoring is performed in a surgical unit. Medical treatment includes diet, rehydration with correction of any electrolyte imbalance, nasogastric tube drainage in cases of vomiting and analgesia. Preventive antibiotic therapy and octreotide are recommended.

In conclusion, trauma to the pancreas is not common and isolated pancreatic trauma is even less common. Isolated pancreatic injury may be overlooked or the diagnosis may be delayed due to subtle initial signs and symptoms. Pancreas injuries can be seen in children presenting with abdominal pain as a result of falling off the bike without any external symptoms. In patients presenting with abdominal blunt trauma, pancreatic injury should always be kept in mind. Contrast-enhanced CT plays an important role in the diagnosis.

\section{Declaration of conflicting interests}

The authors declared no conflicts of interest with respect to the authorship and/or publication of this article.

\section{Funding}

The authors received no financial support for the research and/or authorship of this article.

\section{REFERENCES}

1. Cirillo RL Jr, Koniaris LG. Detecting blunt pancreatic injuries. J Gastrointest Surg 2002;6:587-98.

2. Venkatesh SK, Wan JM. CT of blunt pancreatic trauma: a pictorial essay. Eur J Radiol 2008;67:311-20.

3. Mattix KD, Tataria M, Holmes J, Kristoffersen K, Brown R, Groner J, et al. Pediatric pancreatic trauma: predictors of nonoperative management failure and associated outcomes. J Pediatr Surg 2007;42:340-4.

4. Peclet MH, Newman KD, Eichelberger MR, Gotschall CS, Guzzetta PC, Anderson KD, et al. Patterns of injury in children. J Pediatr Surg 1990;25:85-90.

5. O'Hanlon DM, Shaw C, Fenlon HM, McEntee GP. Traumatic transection of the pancreas. Am J Surg 2002;183:191.

6. Dubois J, Porcheron J, Lacroix M, Menaoui N. Isolated pancreatic neck rupture. Ann Chir 2001;126:863-8. [Abstract]

7. Lin BC, Chen RJ, Fang JF, Hsu YP, Kao YC, Kao JL. Management of blunt major pancreatic injury. J Trauma 2004;56:774-8.

8. Kshirsagar AY, Vekariya MA, Pednekar AS, Mahna A, Gupta V, Patankar R, et al. Isolated pancreatic tail injury: A rare presentation. Ann Med Surg (Lond). 2015;4:230-2.

9. Subramanian A, Dente CJ, Feliciano DV. The management of pancreatic trauma in the modern era. Surg Clin North Am 2007;87:1515-32. 